\title{
Relevance of Five Laws of Library Science in the Contemporary Library Wordd
}

\author{
Dr. B. Ramesh Babu**

\begin{tabular}{ll|} 
1. Introduction & 5. New Interpretations of Five Laws \\
2. The Five Laws of Library Science & 6. Relevance of Five Laws in the \\
3. Appreciation from the LIS & Contemporary World \\
Professionals & 7. Conclusion \\
4. Imperatives Motivated by Dr. S. R. & \\
Ranganathan's Five Laws: Then and \\
Now
\end{tabular}

\begin{abstract}
Dr. S. R. Ranganathan's Five Laws of Library Science were published in 1931 which is a classic work. This article describes in detail the Five Laws of Library Science and their implications on library activities. These laws have provided a scientific approach to library science. They constitute the philosophical basis for work and services of all types of libraries. These also provide guidance in the practice of Library and Information Science. He author emphasises that these will provide source of inspiration and guidance in the years to come. Every student and teacher of library Science and librarian must give a thought to the implications of these laws. In the changing environment of libraries in the emerging society has to fall with in the purview of these laws. The imperatives motivated by these five laws at the time of Ranganathan and in the present days have been identified. The new interpretations of the five laws with the various current nomenclature of Library and Information Science and other allied subjects have been enumerated. These new interpretations of these Laws shows that in today's international world of librarianship, Ranganathan's Five laws are much important and relevant what was before and even it is increasing. These Laws became the cornerstones of the philosophy of the techniques of Western society's library experts. The author concludes that the vision and legacy of Ranganathan will continue to be an inspiration and guiding spirit for the emergence of the new library and information profession. These will serve as source of inspiration and guidance in the years to come. It is not whether Ranganathan is by himself relevant to-day, but it is we who can make him relevant by studying and applying his principles and practices in different areas of library management.
\end{abstract}

Keywords: S. R. Ranganathan, Five Laws of Library Science, Relevance of Five Laws, Contemporary Librarianship, New Interpretations of Five Laws, Imperatives of Five Laws

* This article was originally presented at the International Seminar Commemorating the 80th Anniversary of Ranganathan's “Five Laws of Library Science," held in Daejon, Korea, 20 October 2011.

** Professor, Department of Library and Information Science, University of Madras, India 논문접수일자: 2011년 10월 12일 최초심사일자: 2011년 11월 3일 게재확정일자: 2011년 11월 27일 한국문헌정보학회지, 45(4): 253-269, 2011. 〔http://dx.doi.org/10.4275/KSLIS.2011.45.4.253〕 


\section{Introduction}

Dr. Shiyali Ramamritra Ranganathan (1892-1972), who is often regarded as the Father of Library Science in India, was born in Shiyali, a small village in the Tanjavoor district of Tamilnadu state on 9th August (date current in official use is $12^{\text {th }}$ August) 1892. He was an inventor, educator, librarian and a philosopher (Kumar 1992). He was a library scientist par excellence. He aims to apply scientific method and principles to different areas of library science. In the context of library science, he conceived the Five Laws of Library Science in 1924. The statements embodying these laws were formulated in 1928; i.e. the laws took final form in 1928. His Five Laws of Library Science was published in 1931. This is a classic work, which describes in detail the Five Laws of Library Science and their implications on library activities. These laws have provided a scientific approach to library science. They constitute the philosophical basis for work and services of all types of libraries.

The year 2011 marks the eighty years of the pronunciation of the Five Laws. These laws are still relevant to the international library philosophy. This is the raison d'etre of this paper. I am happy to contribute this paper on the occasion of eighty years of Ranganathan's Five Laws of Library Science for which the Korean Library Association and Korean Society of Library and Information Science jointly organising an International Seminar to mark this occasion and pays tribute to the Father of Library Science.

\section{The Five Laws of Library Science}

Dr. S. R. Ranganathan, considered by librarians all over the world to be the Father of modern Library Science, proposed five laws of library science in the early 1930s. He left a legacy in his concise laws for libraries. Most librarians worldwide accept them as the foundations of the philosophy of their work and service in the library. These five laws have remained a centrepiece of professional values and as powerful inspirations for social change. These basic theories of Library Science continue to directly impact the development of this discipline and the service of all libraries.

1. Books are for use

2. Every reader his/her Book (Books for all) 
3. Every book its Reader

4. Save the time of the Reader

5. Library is a Growing Organism

These are fundamental laws of library science, which provide the rationale for a unifying theory of library science. With the help of these, we can derive postulates, canons and principles applicable in different fields of Library and Information Science (LIS). These also provide guidance in the practice of Library and Information Science. The 24 words of the Laws provided an intellectual framework for understanding all aspects of library work. The laws have been useful in the teaching of different branches of LIS. These are more than mere generalities because they are founded on observation and analysis.

\subsection{First Law - "Books are for use"}

"Books are for use" is the first, most basic law of Library Science. The first law was the intuitive flash of Prof. Ross, his mathematics teacher and the rest of the laws were propounded by Ranganathan (Ranganathan 1931, p.22). While this seems simple and self-evident, librarians at the time felt very conflicted between the desire to promote reading and the urge to protect and conserve their books. He maintained that books should be used, read and circulated. He observed that books were often chained to prevent their removal and that the emphasis was on storage and preservation rather than use. He did not reject the notion that preservation and storage were important, but he asserted that the purpose of such activities was to promote the use of them. Without the use of materials, there is little use of the item. By emphasizing use, Ranganathan refocused the attention of the field to access-related issues, such as the library's location, loan policies, hours and days of operation, such mundanities as library furniture and the quality of staffing.

This law focuses on the selective use of information. For effective use of information there should be proper storage and dissemination of information. Library and Information professionals have always keep in their minds that, they have to serve "Right information, to the right user at the right time". Library automation helps in computerizing library collections, where more than one user can retrieve the same information simultaneously. The OPAC of the library system helps users in accessing the bibliographical information from anywhere. With the help of Information and Communication Technology (ICT) across the globe at all levels, a number of efforts have been taken to promote the use of information. Government has also taken initiatives to serve 
the information to its citizens (up to grassroots level) in the form of e-government projects. Through Internet one can avail information globally. The library and information professionals have to perform the role of information navigator, knowledge manager and information evaluator (Thaker 2007).

This law gives definition both to the concept of an open stack library and to a library that is appointed with tools and furnishings that make the books useful. Books are to be taken from locked back rooms and brought out to welcoming rooms with open shelves. Shelves need to be accessible to more than one user at a time. Libraries are to be located in the midst of their communities. Whatever be the library location, hours of operation, type of furniture and the way in which books are kept, it is the Library Staff that ultimately make or mar a library. A modern librarian who has faith in this law is happy only when the readers make the shelves constantly empty and use the resources comprehensively.

\subsection{Second Law - "Every reader his/her book"}

An extension of "Books are for use," the second law asserts the right of a library patron to have access to any of the library collection. This law suggests that every member of the community should be able to obtain needed information materials. Ranganathan felt that individuals from all social environments are entitled to library service, and that the basis of library use is education. Librarians should have excellent first hand knowledge of the people to be served, and collections should meet the special interests of the community and libraries should promote and advertise their services extensively to attract a wide range of users. The second law is user oriented law. Every citizen has the right to access the information (Right to Information Act 2004). This law guides the library or information professionals to take care of information users, so that they can access information without any obstacle. Here is the necessity of user survey, user study and user education. User Orientation may help in acquiring the need and satisfying the purpose. Presently many Information Centers or Libraries are is self sufficient to serve all types of information needs of a particular client because of information explosion, budget crunches in the library and raising cost of information sources. But through the networking and the consortium approach of the E-journals and E-books, help to meet the changing needs of users (Satpaty 2007).

While the first law brought about change of fundamental nature in librarianship and put an end to the concept of 'Books are for Preservation' the second law carried this objective further and widened the concept from "Books are for the chosen few to books are for all." The approach 
of first law is from the side of books, the approach of the Second law. is from the side of users of information sources on the line of democratic principle. The Second law insists some obligatory functions of government, library authority, library staff and readers in a welfare state. It is ultimate responsibility of the government to give education for all by any means and methods. Books are tools of education. It presupposes the concept of education for all.

This law reveals the fundamental issue of tension between the cost of materials and the basic right of all persons to have access to the materials they need. This makes acquisitions very important. One must always be mindful that since no one individual can own all the 'sources', the libraries must acquire a body of literature or research materials that will benefit each of its readers. The collection must be appropriate to the Library's Mission. Librarians must know the materials, its uses, and how to use it. Information service gains its legitimacy and its purpose from this law. Clearly, it is the business of librarians to know the readers, to know the books, and to actively help in the finding by every person of his or her book (Viswanathan 1986).

\subsection{Third Law - "Every books its reader"}

The third law asserts that at least one community citizen will have an interest in every book in the library, and that every book should be made available for that person. This principle is closely related to the second law but it focuses on the item itself, suggesting that each item in a library has an individual or individuals who would find that item useful. Ranganathan argued that the library could devise many methods to ensure that each item finds it appropriate reader. One method involved in the basic rules for access to the collection, most notably the need for open shelving. Third Law is information oriented. In modern situation information professionals have to accept the information technology to organize and manage information. Except in rural areas, most of the libraries in India are automated. Few of them have taken initiatives in digitizing the collections. Now e-books and e-journals have taken place into the libraries in addition to the print collections. Every piece of information should be serving to users. Thus information professionals have to organize the information in such a manner that maximum information is used by user correctly and properly. Automated technical process of the library collection such as Cataloguing, Indexing, and Abstracting etc. helps users in the context of the third law of Library Science.

The third law emphasises on the arrangement of the library for maximum use. The following devices are to be used to satisfy the Third law of library science : Book selection (Acquisition 
on demand); open Access; shelf Arrangement; Cataloguing entries (all approaches); Reference Service; Opening of popular departments (Women/Children); Publicity methods; Extension services; Finance and Staff Selection.

This law addresses the fundamental issue of open access. In addition, when a library user comes to the library, or gains access to the library resources, there are certain materials that will meet his or her needs. It is the library's job to ensure that the connection between the user and the materials are made, and that the connection is as speedy and practical as possible. There are many ways in which a library can connect its users to its resources such as: Distribution of acquisition lists; New Book displays; Providing Research Guides; Newsletters; and Book Lists.

\subsection{Fourth Law - "Save the time of the Reader"}

This law is recognition that part of the excellence of library service is its ability to meet the needs of the library user efficiently. The fourth law emphasizes on saving the time of the readers by adopting suitable methods. At present time is precious to not only to the reader but also to the library staff. While rendering library service there is time lag or delay in providing materials due to non-availability of materials, language barrier etc. To this end, Ranganathan recommended the use of appropriate business methods to improve library management. He observed that centralizing the library collection in one location provided distinct advantages. The skillful and qualified staff would not only include those who possess strong reference skills, but also strong technical skills in cataloging, cross-referencing, ordering, accessioning, and the circulation of materials (Ramesh Babu 1996a).

This guideline is meant to improve the efficiency of the library. Readers who can quickly locate the book they want will be more satisfied customers. This law highlighted on, how fast information can be delivered to its end users. ICT has helped users in getting their required information into their laptop, palmtop, and desktops. Today's concept of "library without walls" has come into the picture. Through broadband connection information professionals provide information to its clients with in a fraction of second. Day by day Internet is speedy and reaching every user irrespective of the place and time. Perhaps this law is not as self-evident as the others. Nevertheless, it has been responsible for many reforms in library administration. A Library must examine every aspect of its policies, rules, procedures, and systems with one simple criterion 
that saving the time of the reader is vital to the library's mission. Policies must formulate with the needs of the library users in mind. For example, hours of operation must be set in order to ensure appropriate and convenient access, and the collection must be arranged in an inviting, clear, and obvious way so as not to waste the time of the users.

\subsection{Fifth Law - "Library is a Growing Organism"}

Ranganathan realised that libraries need to continually grow in order to survive. They should be constantly accumulating more information sources in their collection, and they should continually adapt to changes in culture, interest and technology. This law focused more on the need for internal change than on changes in the environment itself. He argued that library organizations must accommodate growth in staff, the physical collection, and patron use. This involved growth in the physical building, reading areas, shelving, and space for the catalogue. The 5th law tells us about the vital and lasting characteristics of the library as an institution and enjoins the need for a constant adjustment of our outlook in dealing with it. Libraries grow and change, and will always do so. Collections increase and change, technology changes and budgets change. Change comes along with growth, and in order to be healthy, that change and growth requires flexibility in the management of the collections, in the use of space, in the recruitment, retention and deployment of staff. In the Fifth Law, the word 'organism' implies a 'system' concept; 'growing' connotes a 'living system'.

The fifth law enunciates a basic principle that should govern the planning and organization of libraries. When a library grows, its entire constituents such as books, readers an staff will grow. Every year books are added to the library collection, due to knowledge explosion and the increasing rate of book production. The increase in the book stack affects the shelving accommodation and stack room area. Thus planning library building, furniture and. fittings should have the character of elasticity. There should be provision for future expansion.

According to Lancaster (1986), the observance of fifth law is even more important today with the introduction of modern technology. To quote Lancaster, "Were Ranganathan alive today he would undoubtedly urge us to remember the fifth law. Most likely, he would point out that observance of this law is even more important now than it was fifty years ago. Furthermore, he would give us some leadership, pointed us in the direction in which we should be headed. Therein lies his greatness." 
Keeping in view the information available and growth in the area, it is impossible for the single library to acquire all the information of a subject. There is space problem, staff problem and most importantly the fund problem which every library facing. In the present electronic age, resources are available in electronic forms, such as CD-ROM, DVD, VCD, Optical Disks etc. Due to availability in electronic format of the resources, space problem of the library gets no sense and smaller place can acquire billions of collection. The main problem of the library is availability of inadequate funds. In that case resource sharing and networki9ng between libraries and information centers are very much essential. To sort out the library budget problem, consortium approach has come to the picture making libraries agreeing to share the resources under common platform.

\section{Appreciation from the LIS Professionals}

According to Bhattacharya 'these five laws constitute a fundamental contribution to the development of library science, documentation and information science. They are fundamental because they are relevant in relation to the past of these disciplines; they are relevant in relation to the present day developments, and they will continue to be so in relation to their future development' (Bhattacharya 1984).

Pauline Atherton would like the Hall of Frame Award to be given to Ranganathan for his Five Laws alone (Atherton 1973). These Laws represent the best of Indian philosophy and Indian culture. They have been derived from the source of Indian wisdom, namely the Vedas. They are as much applicable to Library and Information Science as to any other branch of human knowledge or human activity. They cut across all barriers of geography, nationalities, races and cultures. These laws are the "Grammar of the Library Science or Library Profession". They are not just normative principles but the outcome of immense experience, research and talent of the Noble Librarian Dr SR Ranganathan. These Laws "have remained a centrepiece of professional values" (Rubin 2004). In the words of Lancaster, "These laws provided fundamental statements of goals that Information services should strive for, and they are as relevant today as they were … years ago" (Lancaster 1998). The statement of Lancaster implies that what ever changes that take place in procedures, policies and functions of a library in any society, it would come in the framework and validated by these Five Laws. "One of the astounding things about Dr. 
Ranganathan's Five Laws is the depth of meaning compressed into so few words. Such concision is characteristic of Western poetry and Eastern teaching (secular and spiritual)" (Gorman 1998). These have made an impact on the growth and development of theory and practice. These will provide source of inspiration and guidance in the years to come. Every student and teacher of library Science and librarian must give a thought to the implications of these laws. 'The laws themselves have as much validity now as they ever did. They have been formulated in fewer than 25 words" (Graves 1958). Sayers (1957) regards these laws as "a work of great simplicity which conceals depths and yet reveals what may be called the spiritual but intensely practical springs of activity".

Therefore, in the changing environment of libraries in the emerging society has to fall with in the purview of these laws (Parekh 2007). These brief statements remain as valid (in substance if not in expression) today as when they were promulgated, concisely representing the ideal service and organizational philosophy of most libraries today. These laws are a perennial source of inspiration for services and guidance, for the dynamic development of the subject. They have been widely accepted as the definitive statement of ideal library service.

\section{Imperatives Motivated by Dr. S. R. Ranganathan's Five Laws: Then and Now}

\begin{tabular}{|c|c|c|c|}
\hline S.No. & Laws & Ranganathan's Times & In the Present times \\
\hline 1 & Books are for use & $\begin{array}{l}\text { Ensure the circulation of books and not to } \\
\text { be placed just on the shelf untouched by } \\
\text { the users. }\end{array}$ & $\begin{array}{l}\text { Assure the access of online resources so that } \\
\text { they are readily available where and when } \\
\text { they are needed. }\end{array}$ \\
\hline 2 & $\begin{array}{l}\text { Every reader his/her } \\
\text { book }\end{array}$ & $\begin{array}{l}\text { Obstacles between the books and its reader } \\
\text { to be removed in order to satisfy the principle } \\
\text { of education (and books) for all. }\end{array}$ & $\begin{array}{l}\text { Eliminate the obstacles that prevent users } \\
\text { from making effective use of electronic } \\
\text { resources. }\end{array}$ \\
\hline 3 & $\begin{array}{l}\text { Every book its } \\
\text { reader }\end{array}$ & $\begin{array}{l}\text { Ensure the easy access of books to the user } \\
\text { through a well-cross-referenced catalogue. }\end{array}$ & $\begin{array}{l}\text { Integrate electronic resources into virtual } \\
\text { learning environments and other web pages } \\
\text { of the institution. }\end{array}$ \\
\hline 4 & $\begin{array}{l}\text { Save the time of the } \\
\text { reader }\end{array}$ & $\begin{array}{l}\text { Avoid the wastage of user's time involved } \\
\text { in search for particular books by creating } \\
\text { effective catalogues. }\end{array}$ & $\begin{array}{l}\text { Provide meta searching capabilities to } \\
\text { search entire set of electronic resources and } \\
\text { link resolves so that users get access to the } \\
\text { best source. }\end{array}$ \\
\hline 5 & $\begin{array}{l}\text { Library is a growing } \\
\text { organism }\end{array}$ & $\begin{array}{l}\text { Regard libraries as part of the larger } \\
\text { community. }\end{array}$ & $\begin{array}{l}\text { Offer anytime, anywhere, access to } \\
\text { libraries; the Invisible Web. }\end{array}$ \\
\hline
\end{tabular}




\section{New Interpretations of Five Laws}

The Five Laws were interpreted and reworded from time to time. The following are some of such interpretations:

Replacing Books with Documents (Ranganathan 1963)

Documents are for use

Every reader his/her document

Every document its reader

Save the time of the reader

A library is a growing organism

Replacing Books with Information (Bhattacharyya 1983, p.231)

Information is for use

Every Information user his/her information

Every piece of information its user

Save the time of the information user

The universe of information is ever growing

\section{Replacing Books with E-Resources}

E- Resources are for use

Every E- Resource its user

Every user his/her E- Resource

Save the time of the user

E-resource is a growing organism

Visualizing the Web through Five Laws (Noruzi 2004).

Web resources are for use

Every user his or her web resource

Every web resource its user

Save the time of the user

The Web is a growing organism 
Lennart Björneborn, in his doctoral research entitled, Small-World Link Structures across an Academic Web Space - a Library and Information Science Approach, attempted to rephrase the Five laws in the context of Link.

\section{Replacing Books with Links}

Links are for use

Every surfer his or her link

Every link its surfer

Save the time of the surfer

The Web is a growing organism

\section{Replacing Books with Search Engines}

Search Engines are for Use

Every Searcher His / Her Search Engine

Every Search Engine its Searcher

Save the Time of the Searcher

Search Engine is a growing organism

\section{Replacing Books with Software}

Software is for use

Every user his or her software

Every software its user

Save the time of the user

A software is a growing organism

\section{Replacing Books with Institutional Repositories (IR)}

Institutional Repositories (IR) are for use

Every user his/her IR

Every IR its user

Save the IR for future

IR is a growing organism

Furthermore, based on Ranganathan's laws, Thompson (1992) in protesting against a library 
services, revised Ranganathan's laws to the following statements:

Books are for profit

Every reader his bill

Every copy its bill

Take the cash of the reader

The library is a groaning organism

Gorman has reinterpreted Ranganathan's laws in the context of today's library and its likely future as follows:

1. Libraries serve humanity

2. Respect all forms by which knowledge is communicated

3. Use technology intelligently to enhance service

4. Protect free access to knowledge

5. Honor the past and create the future (Gorman 1995)

Gorman (1998a, b) believes that S.R. Ranganathan invented the term 'Library Science' and beautifully demonstrates how his laws are applicable to the future issues and challenges that librarians will face. Gorman's laws are a valuable supplement or extension to Ranganathan's laws and should be used to help carry out and understand Ranganathan's laws in the modern context.

Let us see how Ranganathan's Five Laws lend themselves to various interpretations in diverse fields (Sethi 1986, pp.103-104).

\section{Resources}

First Law : Resources are for use

Second Law : Each person his/her share

Third Law : Each resource its optimum use

Fourth Law : Conserve the resources

Fifth Law : Demand for resources is a growing phenomenon, supply is not

\section{Public Utilities: Railways}

First Law : Railways are for use 
Second Law : Each passenger his/her seat

Third Law : Each seat its passenger

Fourth Law : Save the time of passenger

Fifth Law : Traffic is a growing organism

\section{Public Administration}

First Law : State is supreme

Second Law : Each citizen his/her rights (and duties)

Third Law : Equal opportunity for all

Fourth Law : Protect the citizens

Fifth Law : Administration functions continue to grow

\section{Jurisprudence}

First Law : Law is supreme

Second Law : Each person access to law

Third Law : Each law its adherents

Fourth Law : Save the time (and expense) of litigants

Fifth Law : Litigation continues to grow

\section{Religion}

First Law : God is supreme

Second Law : Each person his/her faith

Third Law : Each faith its followers

Fourth Law : Save all the forms of life

Fifth Law : As sins grow, so does the faith

\section{Society}

First Law : Society is an organized institution

Second Law : Each individual his rightful place

Third Law : Each social role its rightful operator

Fourth Law : Observe the norms of society

Fifth Law : Society is a growing organism 


\section{Relevance of Five Laws in the Contemporary World}

Five Laws entered in the vision and objective statement of different types of libraries all over the world. These new interpretations of these Laws shows that in today's international world of librarianship, Ranganathan's Five laws are much important and relevent what was before and even it is increasing.

In 1999, Timo Kuromenn and Pekkarinen Paivi in a paper entitled 'Ranganthan Revisited: A Review Article' analysed the Five Laws of Ranganathan and felt that there is a need of some supplementary laws to the original Five Laws in context of technological advances of today. Two supplementary laws in addition to the original Five Laws of Ranganthan are:

1. Every reader his library

2. Every writer his contribution to library

The first supplementary law relates to the technological changes, particularly in telecommunications, that have taken place since Ranganathan's time. The second supplementary law is concerned with the individual reader's or citizen's freedom of expression, as a right that can be put into practice and not merely articulated in principle. The more recent and concrete proof of the global acceptance of Ranganathan's Five Laws of Library Science is provided by the Digital Library Information Science and Technology (dList), an open access archive for the Information Sciences, of the School of Information Resources and Library Science Learning Technologies Centre, University of Arizona. They have included in their e-prints Ranganathan's book Five Laws of Library Science as a classic in LIS. Its abstract is also available on their website (Dasgupta 2007). Whether one looks to Ranganathan's original Five Laws of Library Science or to any one of the many new interpretations of them, one central idea is immediately clear: Libraries and the Web exist to serve people's information needs (Noruzi 2004).

It is a well established fact that the Five Laws of Library Science have been accepted as fundamental laws and there is no dispute on this. There are only elaborations depending on the changing information environment. Infact even before computers made their entry; Ranganathan had envisaged their importance in information transfer. The laws can also be interpreted like: Eliminate the obstacles that prevent users from making effective use of electronic sources; Integrate electronic resources into virtual learning environments of the institution; provide metasearching capabilities 
so that users can search entire sets of electronic resources ; and offer $24 \times 7$, anytime access to libraries through electronic networks.

Five Laws of Library Science became the cornerstones of the philosophy of the techniques of Western society's library experts. Ranganathan unfortunately lived at a time when computers had not come into existence or rather had not made much in roads in the field of library and information science. His contributions in various fields indicate that he lived very much ahead of his time. The vision and legacy of Ranganathan will continue to be an inspiration and guiding spirit for the emergence of the new library and information profession. It is not whether Ranganathan is by himself relevant to-day, but it is we who can make him relevant by studying and applying his principles and practices in different areas of library management (Ramesh Babu 1996b).

\section{Conclusion}

It can be concluded that Ranganathan's Five Laws essentially constitute a fundamental contribution to the development of Library Science, Documentation and Information Science. They are fundamental because they are relevant in relation to the past, present-day developments, as well as future developments. Although the Five Laws of Library Science consist of five short statements, the boldness and clarity of thought behind these is remarkable. These statements appear to be too simple but in reality these laws are quite complicated. These provide guidance and rationale for practice and teaching of Library and Information Science. The laws have been useful in teaching of different branches of Library Science. These have made an impact on the growth and development of theory and practice. These will serve as source of inspiration and guidance in the years to come.

Ranganathan's Five Laws of Library Science are applicable to all fields of library activities. Now we have entered into digital era. Inspite of multidimensional development in different areas of library work and service and their enrichment with the application of modern technology Five Laws of Library Science are equally applicable till date, since its inception. Today ICT application permits all human activities. Five Laws of Library Science was written eighty years back and inspite of having so many changes in Library world, these Five Laws still relevant in today's context. The five laws are equally valid in the present digital / information age as they have been in the conventional library environment. The five laws are the source and sum of all the 
practices of times, yesterday, today and tomorrow. Even eighty years of its origin Ranganathan's Five Laws are very much popular and applicable in this present electronic and digital era. These Laws can never be obsolete as long as human civilization and culture exist and consigned to oblivion in spite of the digital divide and information literacy barrier.

As far as Indian Librarianship is concerned, the present status and respect we are enjoying is due to the efforts of Dr. S. R. Ranganathan. It is our bounden duty to pay rich tributes by not only carrying his message forward to the generations to come, but also to preserve his legacy.

\section{References}

[1] Atherton, Pauline A. 1973. Putting knowledge to work: an American view of Ranganathan's Five Laws of Library Science., New Delhi: Vikas.

[2] Bhattacharya, G. 1984. "Relevance of Ranganathan's ideas in the context of modern development." New Trends in international librarianship. Edited by Mohan Rajan. New Delhi: Allied. pp.226-333.

[3] Cana, M. 2003. July 5. Open source and Ranganathan's five laws of library science. Retrieved October 22, 2004, from <http://www.kmentor.com/socio-tech-info/archives/000079.html>.

[4] Dasgupta, A. 2008. "Ranganathan's Five Laws and their impact in digital era." Changing Library Scenario in Digital Era. Edited by Narendra Lahkar. Guwahati: Assam College Librarian's Association. pp.190-194.

[5] Dasgupta, A. 2007. "Library staff and Ranganathan's Five Laws." IASLIC Bulletin, 52(4): 195.

[6] Garfield, E. 1984. "A tribute to S.R. Ranganathan, the father of Indian Library Science. Part 1. Life and Works." Current Contents, 6 (February): 5-12.

[7] Gorman, M. 1995. "Five new laws of librarianship." American Libraries, 26(8): 784-785.

[8] Gorman, M. 1998a. Our singular strengths: mediations for librarians. Chicago, IL: American Library Association.

[9] Gorman, M. 1998b. "The five laws of library science: then \& now." School Library Journal, 44(7): 20-23.

[10] Graves, F. H. 1958. "The Five Laws of Library Science.” Special Libraries, 49: 271.

[11] Kumar, P. S. G. 1992. Ranganathan: a Multi-faceted Personality. New Delhi, D.K. Publishing Corporation.

[12] Lancaster, F. W. 1998. If You Want to Evaluate Your Library. London: Library Association. p.8. 
[13] Leiter, R.A. 2003. "Reflections on Ranganathan's five laws of library science." Law Library Journal, 95(3): 411-418.

[14] Noruzi, Alireza. 2004. "Application of Ranganathan's Laws to the Web." Webology, 1(2), Article 8. Available at: <http://www.webology.org/2004/v1n2/a8.html>.

[15] Parekh, H. 2007. "Five Laws of Library Science: continuing foundations in an information society." DLibCom, 2(8-9)(Aug.-Sept.): 7-9.

[16] Rajagopalan, T. S., ed. 1986. Ranganathan's Philosophy: Assessment, Impact and Relevance. New Delhi: Vikas.

[17] Ramesh Babu, B. 1996a. "Reflections on Ranganathan's staff formula." International and Comparative Librarianship and Information Systems. Edited by P.N.Kaula and others. Delhi: B.R.Publishing Corporation. Vol.1, Section 30.

[18] Ramesh Babu, B. 1996b. "Relevance of Ranganathan's concepts and ideas in the contemporary librarianship: an analysis." International and Comparative Librarianship and Information Systems. Edited by P.N.Kaula and others. Delhi: B.R.Publishing Corporation, Vol.1, Section 9.

[19] Ranganathan, S. R. 1931. Five Laws of Library Science. Madras: Madras Library Association.

[20] Ranganathan, S. R., ed. 1963. Documentation and Its Facets. Bombay: Asia publishing House.

[21] Rubin, Richard E. 2004. Foundations of Library and Information Science. $2^{\text {nd }}$ ed. New York: Neal-Schuman Publishers.

[22] Satpaty, Kishore Chandra, \& Soni, Divya. 2007. "India library consortia \& five laws of library science.” XXVI All India Conference of IASLIC. Jamia Milia Islamia.

[23] Sayers, W.C.B. 1957. "Preface." Ranganathan SR, Prolegomena to Library Classification. $2^{\text {nd }}$ ed. Bombay: Asia Publishing House. p.19.

[24] Sethi, A. R. 1986. "Obsolescene in Ranganathan?" Ranganathan's Philosophy: Assessment, Impact and Relevance. Edited by TS Rajagopalan, New Delhi: Vikas. pp.103-104.

[25] Thaker, Urmila, \& Rawal, Chandrakant. 2007. "Five laws of library science in new perspectives." DLIBCOM Journal of Digital Library Communication, 2 (8-9): 11-14.

[26] Thompson, Jim. 1992. "The five laws of library science." Newsletter on Serials Pricing Issues, 47(September 13). Retrieved on October 12, 2004, from <http://www.lib.unc.edu/prices/1992/PRIC47.HTML\#47.3>.

[27] Viswanathan, C. G. 1986. "Ranganathan's five laws of library science and their relevance in the modern context." Lucknow Librarian, 18(1). Mar. 